\title{
FOREST SOIL HETEROGENEITY AND SOIL SAMPLING PROTOCOLS ON LIMESTONE OUTCTOPS: EXAMPLE FROM SW CHINA
}

\author{
PROTOKOL VZORČENJA IN HETEROGENOST GOZDNE PRSTI \\ NA APNENČASTIH IZDANKIH: PRIMER IZ JZ KITAJSKE
}

\author{
ZHOU Yunchao ${ }^{1}$, WANG Shi-jie ${ }^{1 *}$, LU Hong-mei ${ }^{1,2}$, XIE Liping $^{1,2} \&$ XIAO De’an ${ }^{1,2}$
}

\begin{abstract}
UDC $630^{\star} 114: 551.44(510)$

Zhou Yunchao, Wang Shi-jie, Lu Hong-mei, Xie Liping \& Xiao De'an: Forest Soil Heterogeneity and Soil Sampling Protocols on limestone outctops: Example from SW China

Forest soil heterogeneity of outcrop karst was studied by testing soil organic carbon at a selected $20 \mathrm{~m} \times 30 \mathrm{~m}$ plot set up in Maolan primitive karst forest area, southern Guizhou Province, China. 90 microhabitats in the plot are roughly classified into 7 distinct microhabitat There was great heterogeneity in the plot not only for soil distribution but for great difference of soil organic carbon content. Soil organic carbon (SOC) contents were much higher, ranging from $40.1 \mathrm{~g} / \mathrm{kg}$ to $203.5 \mathrm{~g} / \mathrm{kg}$. The CV (coefficient of variation) value of SOC from 38 soil sampling points, 22 sampling microhabitats, each microhabitat type, and individual microhabitat was $43 \%, 41 \%, 2.2 \%$ to $42 \%, 14 \%$ to $57.3 \%$ respectively. This showed high soil heterogeneity in terms of soil distributing pattern, size and soil organic carbon SOC content in outcropped karst. Different methods were applied to calculate SOC content in the plot. Small discrepancies suggested that the mixed soil samples collected from the major microhabitat types covering $95 \%$ soil distributing area were capable of representing soil nutrient status of the whole plot.

Keywords: karst, prst, organic carbon, sampling protocol,
\end{abstract} Southwestern China.

\begin{abstract}
Izvleček
UDK $630^{\star} 114: 551.44(510)$

Zhou Yunchao, Wang Shi-jie, Lu Hong-mei, Xie Liping \& Xiao

De'an: Protokol vzorčenja in heterogenost gozdne prsti na apnenčastih izdankih: primer iz JZ Kitajske

$\mathrm{Z}$ analizo organskega ogljika smo raziskovali heterogenost gozdne prsti na testni površini velikosti $20 \mathrm{~m}$ x $30 \mathrm{~m}$. Raziskave so potekale v gozdnem območju Maolan v južnem delu province Guizhou, Kitajska. Na površini smo našli 90 mikrohabitatov in jih razvrstili $\mathrm{v} 7$ različnih mikrohabitatnih tipov glede na položaj vzorčnega mesta. Tudi količina organskega ogljika (SOC, soil ogrganic content) v prsti kaže na veliko heterogenost prsti. Ta zavzema vrednosti med 40,1 g/l in 203,5 g/l. Koeficient variacije SOC na 28 vzorčevalnih mestih vzorčenj je $43 \%$, med 22 mihrohabitati $41 \%$, znotraj mikrohabitatnega tipa $2.2 \%$ do $42 \%$ in znotraj posameznega mikrohabitata med $14 \%$ in $57,3 \%$. Pri izračunu SOC smo uporabili različne metode, majhna odstopanja pa kažejo, da mešani vzorci prsti iz glavnih mikrohabitatnih tipov, ki pokrivajo 95\% testne površine, reprezentativno predstavljajo vsebnost hranil na celotni testni površini.

Ključne besede: kras, prst, organski ogljik, vzorčenje prsti, jugozahodna Kitajska.
\end{abstract}

\footnotetext{
${ }^{1}$ State Key Laboratory of Environment Geochemistry, Institute of Geochemistry Chinese Academy of Sciences, Guiyang, e-mail: fc.yczhou@gzu.edu.cn,wangshijie@vip.gyig.ac.cn;

${ }^{2}$ Graduate School of Chinese Academy of Sciences, Beijing, e-mail: hongmeilu0826@126.com, Xeliping@163.com, xiaodean@hotmail.com
}

Received/Prejeto: 28.8.2009 


\section{INTRODUCTION}

Soil heterogeneity has been world-wide interested recently (Boerner et al. 1998; Wang et al. 1998; Park \& Vlek 2002; Yang et al. 2002; Jhorar et al. 2004). Researchers either focused on assessing properties of heterogeneous soils based on valid sampling protocols or on identifying the aims to study the validities of sampling protocols (Theocharopoulos et al. 2001; Barahona \& Iriarte 2001; Fernando et al. 2001; Donohue 2002; Myeong et al. 2003; Tamminen 2003; Kulmatiski \& Beard 2004; Whalen 2004; Bramley et al. 2005). However, all the previous studies about soil heterogeneity were only conducted in areas of intact soil mantles; no study was conducted in outcrop karst mountainous regions.

Attentions have been absorbed to outcrop karst soils (Drew 1983; Gillieson et al. 1994; Atalay 1997; Cerda 1998; Shang \& Tiessen 2003; Parise \& Pascali 2003; Wang et al. 2004a) for soil erosion (Cerda 1998), soil sediment recorded paleoenvironment (Sauro et al. 2009), environmental pollution (Parise \& Pascali 2003) and soil carbon sequestration (Shang \& Tiessen 2003). Because of susceptible karst environment, pressure of sharp population growth accelerated soil erosion and karst desertification (or karst desert, rocky desert, bare karst). Karst desert area in Guizhou, China, one of the biggest karst desertification center in the world, is up to $11 \times 10^{4} \mathrm{~km}^{2}$, and also accelerating in much higher speed (Wang et al. 2004a). With the high speed expanding of urbanization and industrialization, high quality arable land was invaded, ecosystems were interrupted, especially soils. Karst rocky desertification, one of the serious eco-environmental problems, happened in karst mountainous areas in southwestern China (Wang et al. 2004a, b), several studies have concerned on soil property in this region (Liu et al. 2005; Li et al. 2006; Zhang et al. 2006). Unfortunately, the distinct soil heterogeneity of karst mountainous regions was not taken into consideration in their soil sampling methods. How can we appropriately evaluate the change of outcrop karst soil quality?

The present study was undertaken with the following two objectives: (1) comprehending the pattern of soil heterogeneity of outcrop karst, and (2) proposing a valid way to sample in outcrop karst soil.

\section{MATERIALS AND METHODS}

\section{STUDY AREA}

Maolan karst forest $\left(107^{\circ} 52^{\prime} 10^{\prime \prime}-108^{\circ} 05^{\prime} 40^{\prime \prime} \mathrm{E}, 25^{\circ} 09^{\prime} 20^{\prime \prime}\right.$ $-25^{\circ} 20^{\prime} 50^{\prime \prime} \mathrm{N}$ ) is located in southern Guizhou Province, China. This area has preserved a primitive forest ecosystem with an area of 19,640 hectares, which is the only karst virgin forest survived at the same latitude on the Earth. This area topographically presents a typical, welldeveloped peak cluster karst (fengcong in Chinese). Peak clusters constitute a subtype of tower karst, characterized by many dolines scattered among groups of large stone peaks sharing the same base. The outcropped rocks are composed of limestone of Carboniferous period, covering around $70 \% \sim 80 \%$ of the forest. The subtropical monsoon climate is warm and humid with an average annual temperature of $15.3^{\circ} \mathrm{C}$ and average annual precipitation of $1,752.5 \mathrm{~mm}$. More than $81 \%$ precipitation (about $1,419.6$ $\mathrm{mm}$ ) occurs from April to September. Forest ecosystem has developed diverse plants, involving 154 families, 514 geneses, 120 species of vascular bundle plants, of which there are 143 families, 494 geneses, and 1,172 species of spermatophytes (Lan 1987; Chen 1997). Recently, Maolan karst forest ecosystem has attracted more attention worldwide to multidisciplinary researches pertaining to biology, ecology, geology, and environment.
The investigated area was specified on a typically plot of $20 \times 30 \mathrm{~m}^{2}\left(108^{\circ} 02^{\prime} 29^{\prime \prime} \mathrm{E}, 25^{\circ} 16^{\prime} 21^{\prime \prime} \mathrm{N}\right.$; Fig. 1) with a slope of $38^{\circ}$, with predominant yellow limestone soil. Soil layers are shallow from several $\mathrm{cm}$ to $60 \mathrm{~cm}$, soil fragments distribute in patches among bare limestone and soil constructions generally show transition tendency from A-B-R to A-R.

\section{FIELD INVESTIGATION}

Prior to sampling soil, soil distribution was carefully investigated and classified. The identified 90 individual microhabitats could be roughly classified into 7 microhabitat types on the basis of micro-terrain, ratio of exposed rock, soil covering site and size, etc. (Fig. 1). (1) Rocky: almost all exposed rocks. (2) Soil: ratio of exposed rock was lower than $30 \%$, soil covered uniformly, and the area was larger (length and width were more than $2 \mathrm{~m}$ ). (3) Rock-soil: ratio of exposed rock was more than $30 \%$; soil cover was less than (2). (4) Karren: Depth/width ratio was less than 2 with varied thickness of soil at the bottom of karren. (5) Grike: Depth/width ratio was more than 2 with thin soil at the bottom of the grike. (6) Stone pit: irregular deep-eroded depression with $0.1 \sim 1 \mathrm{~m}^{2}$ soil cover. (7) Stone hole: various sizes of channels formed by water 

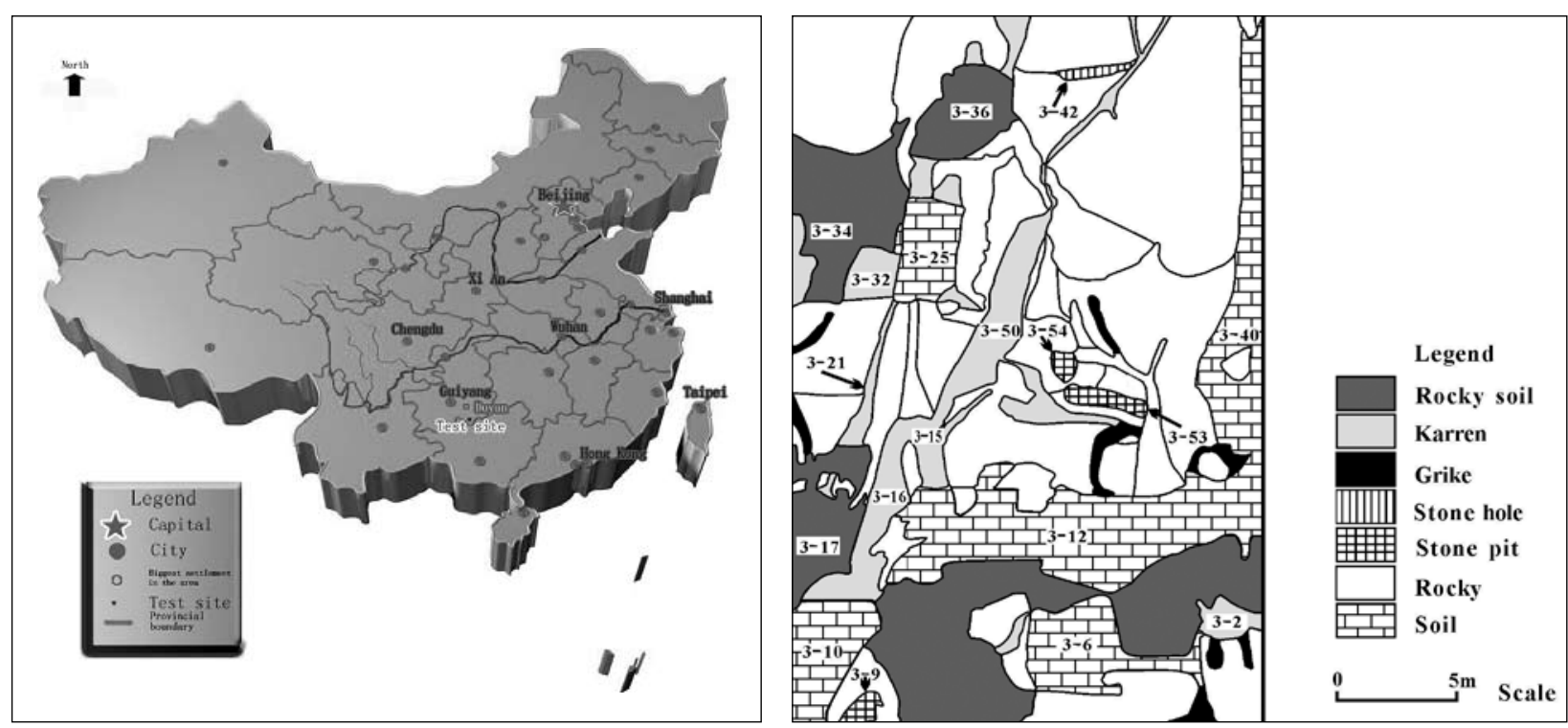

Fig. 1: Location of test site and the distribution of microhabitats in the plot (arrow indicated the number of microhabitat, and the 3-53 indicated the microhabitat number in the plot).

corroded (Fig. 2, Tab. 1). Soil was covering $170 \mathrm{~m}^{2}$, only $28.4 \%$ of the plot, but the outcropped carbonate rocks covering $71.6 \%$. It was difficult to apply grids sampling method (Leo 1963; Shang \& Tiessen 2003) in outcrop karst for the reason that soil was isolated by limestone rocks, soil properties of each individual microhabitat was driven by different water, air, heat, organism, etc.

Tab. 1: Statistics of various microhabitat types in the investigated plot.

\begin{tabular}{|c|c|c|c|c|c|c|}
\hline $\begin{array}{l}\text { Microhabitat } \\
\text { type }\end{array}$ & Description & Number & Size $/ m^{2}$ & $\begin{array}{l}\text { Size proportion } \\
\text { (Plot base) } / \%\end{array}$ & Soil size / $m^{2}$ & $\begin{array}{l}\text { Soil proportion } \\
\text { (Plot base) } / \%\end{array}$ \\
\hline Rock & $\begin{array}{l}\text { Large size of carbonate exposure. } \\
\text { Litter but less soil is available at small } \\
\text { flat or hollow sites }\end{array}$ & 46 & 291.1 & 48.5 & 0 & 0 \\
\hline Soil & $\begin{array}{l}\text { Rock exposure rate }<30 \% \text {, } \\
\text { well-proportioned soil layer, } \\
\text { size }>2 \mathrm{~m} \times 2 \mathrm{~m} \text {. }\end{array}$ & 14 & 49.7 & 8.4 & 26.5 & 15.6 \\
\hline Rock-soil & $\begin{array}{l}\text { Rock exposure rate }>30 \% \text {, } \\
\text { size of soil layer }<2 \mathrm{~m} \times 2 \mathrm{~m} \text {. }\end{array}$ & 5 & 117.0 & 19.5 & 93.0 & 54.7 \\
\hline Karren & $\begin{array}{l}\text { Rock erosion gully, depth/ width } \\
\text { ratio }<2 \text {, disproportionate soil layer } \\
\text { and litter accumulated at bottom. }\end{array}$ & 6 & 120.6 & 20.1 & 41.5 & 24.4 \\
\hline Grike & $\begin{array}{l}\text { Depth/width ratio }>2 \text {, } \\
\text { small amounts of soil at bottom, } \\
\text { litter accumulated. }\end{array}$ & 3 & 5.1 & 0.8 & 2.3 & 1.4 \\
\hline Stone pit & $\begin{array}{l}\text { Irregularly-shaped eroded } \\
\text { depression, soil distributing size } \\
\text { is around } 0.1-1 \mathrm{~m}^{2} \text {. }\end{array}$ & 11 & 10.9 & 1.8 & 1.1 & 0.6 \\
\hline Stone hole & $\begin{array}{l}\text { Tubular channels of various sizes } \\
\text { from water erosion, } 10-30 \mathrm{~cm} \\
\text { at depth. }\end{array}$ & 5 & 5.6 & 0.9 & 5.6 & 3.3 \\
\hline Total & & 90 & 600 & 100 & 170 & 100 \\
\hline
\end{tabular}




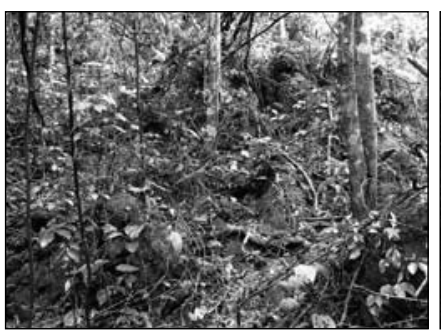

1) Rocky

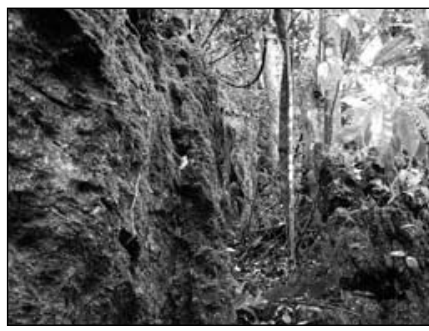

4) Karren

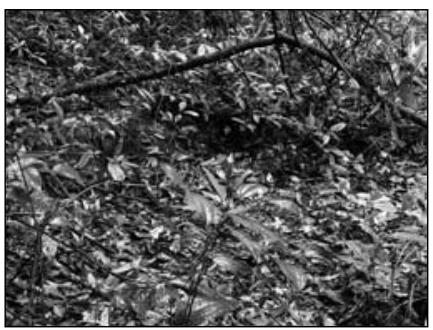

2) Soil

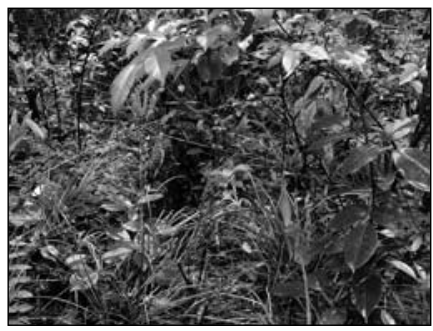

5) Grike

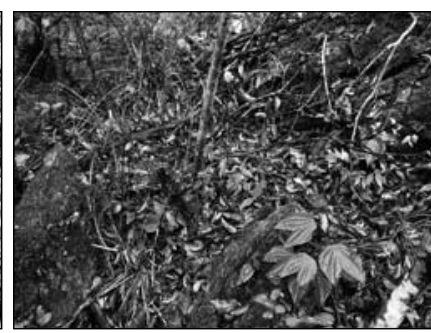

3) Rock-soil

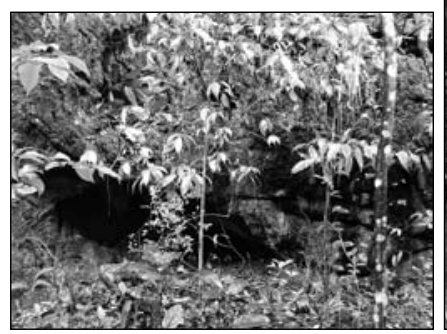

6) Stone hole

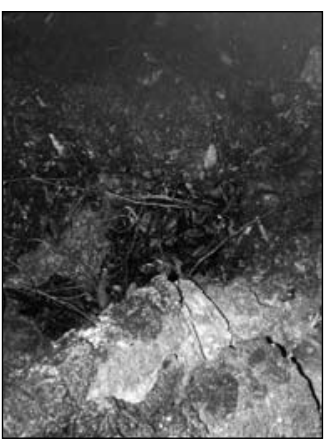

7) Stone pit

Fig. 2: Type of microhabitats (photo: a-rocky; b-soil; c-rock-soil; d-karren; e-grike; f-stone pit; g-stone hole. Photos: S. J. Wang).

\section{SOIL SAMPLING AND ANALYSIS}

Soil samples were collected from microhabitats to a depth of $20 \mathrm{~cm}$ (or less where soils were too shallow). Only one sample was collected at a microhabitat which is topographically flat with uniform litter layers, but three replicated samples were collected from 8 individual microhabitats existing significant differences in litter depth, slope, etc. At each sampling site, 3-5 points were collected and mixed to be a final sample. No soil sample was collected from the microhabitats of all rocky and grike, some karrens and rock-soil for the reason of limited soil depth. 38 soil samples were collected from 22 individual microhabitats where sufficient soils are available in the plot. Each sample was $1 \mathrm{~kg}$ and air-dried, stones, visible litters and roots were removed before grinding to $2 \mathrm{~mm}$, and plant micro piece was removed by using a plastic bar of static electricity produced by plastic bar friction. A sub-sample was milled to pass $0.25 \mathrm{~mm}$ sieve to test SOC by using potassium dichromate oxidation method of Walkey-Black procedure (Nelson \& Sommers 1982).

\section{RESULTS AND DISCUSSION}

\section{SOIL HETEROGENEITY IN TERMS OF SOIL DISTRIBUTION}

Soil heterogeneity in the investigated plot was obvious in terms of soil distribution. Rocky, one of microhabitat types, predominated in size, accounts for almost $48.5 \%$ of the plot, soil and rock-soil for $28 \%$, karren for $20 \%$, and grike, stone pit and stone hole for 3.5\% (Tab. 1). Soil covered in five microhabitat types (soil, rock-soil, karren, stone pit and stone hole) account for more than 99\% of the total $170 \mathrm{~m}^{2}$ soil area. Among them, three major microhabitat types involved of soil, rock-soil, karren, account for about $95 \%$ of the total soil area. Soil distributed in patches among bare limestone.

\section{SOIL HETEROGENEITY IN ORGANIC CARBON}

Soil organic carbon (SOC) was extremely heterogeneous in the plot, ranging from $40.1 \mathrm{~g} / \mathrm{kg}$ to $203.5 \mathrm{~g} / \mathrm{kg}$ (Tab. 2). Compared with red soil of $26 \mathrm{~g} / \mathrm{kg}$ and yellow soil of $28 \mathrm{~g} / \mathrm{kg}$ of forest and/or grasslands in China (Xiong \& Li 1987), mass humus combined with $\mathrm{Ca}^{2+}$ and $\mathrm{Mg}^{2+}$ to form highly polymer for the reason of Ca-rich in karst soil, calcium humic acid was stabilized and accumulated in karst soil (He et al. 2001). The CV (coefficient of variation) value of SOC from 38 soil sampling points was $43 \%$ (Tab. 2), much higher than those in non-karst areas. For instance, the CV of organic carbon of $625 \mathrm{~m}^{2}$ irrigationsilting soils in Aksu area of Xinjiang, China was not more than $17.84 \%$ (Yang et al. 2002). 
With respect to 22 microhabitats, the $\mathrm{CV}$ of organic carbon was $41 \%$, close to $43 \%$ from all the 38 soil-sampling points (Tab. 2).

SOC contents of the five microhabitat types, accounted for $99 \%$ of the total soil area in the plot, were $40.1 \sim 107.2 \mathrm{~g} / \mathrm{kg} \quad$ (Soil), $86.9 \sim 165.8 \mathrm{~g} / \mathrm{kg} \quad$ (rock-soil), $47.3 \sim 203.5 \mathrm{~g} / \mathrm{kg}$ (karren), 41.0 72.0 g/kg (stone pit) and $102.5 \sim 154.7 \mathrm{~g} / \mathrm{kg}$ (stone hole), respectively. Except for microhabitat type of karren, the variation coefficients of SOC in the other 4 of microhabitat types varied within the range of $22 \% \sim 28 \%$, much lower than $41 \%$ calculated on the basis of 22 individual microhabitats (Tab. 2). Meanwhile, it could be seen that average SOC content in microhabitat types showed significant variation from one another, the order was: stone pit $(124.8 \mathrm{~g} / \mathrm{kg})>$ karren $(121.1 \mathrm{~g} / \mathrm{kg})>$ rock-soil $(112.4 \mathrm{~g} / \mathrm{kg})>$ Soil $(81.5 \mathrm{~g} / \mathrm{kg})>$ stone hole $(57.8 \mathrm{~g} / \mathrm{kg})$. Particularly, dominated 3 microhabitat types (soil, rock-soil and karren), more than 95\% ren had the greatest soil heterogeneity. Soil covering size for each of the 8 individual microhabitats ranged from $1.5 \mathrm{~m}^{2}$ to $15.7 \mathrm{~m}^{2}$ (Tab. 1). The CV values of SOC in the karst regions were relatively large when compared with that in non-karst regions in the same scale. For example, $\mathrm{CV}$ of surface soil organic carbon was $11.2 \%$ for a $50 \mathrm{~m}^{2}$ plot in the Xilin River watershed in Inner Mongolia, but was only $6.25 \%$ for the $4 \mathrm{~m}^{2}$ surface soil in the same plot (Wang et al. 1998). Therefore, it could be inferred that soil samples should be collected to represent individual microhabitat in the karst region by using a multi-point sampling protocol.

\section{ESTIMATION OF SOIL ORGANIC CARBON IN OUTCROP KARST AREA AND SOIL SAMPLING PROTOCOL}

It was evident from the above discussion that karst forest soil was significantly heterogeneous. This was manifested

Tab. 2: Concentrations of soil organic carbon in each investigated microhabitat types in the plot.

\begin{tabular}{lcccccc}
\hline Microhabitat type & $\begin{array}{c}\text { Number of } \\
\text { samples }\end{array}$ & $\begin{array}{c}\text { Minimum } \\
(\mathbf{g} / \mathrm{kg})\end{array}$ & $\begin{array}{c}\text { Maximum } \\
(\mathbf{g} / \mathrm{kg})\end{array}$ & $\begin{array}{c}\text { Average } \\
(\mathbf{g} / \mathbf{k g})\end{array}$ & $\begin{array}{c}\text { SD } \\
(\%)\end{array}$ \\
\hline Karren & 6 & 47.3 & 203.5 & 121.1 & 50.3 & 42 \\
\hline Soil & 5 & 40.1 & 107.2 & 81.5 & 22.8 & 28 \\
\hline Rock-soil & 3 & 86.9 & 165.8 & 112.4 & 26.9 & 24 \\
\hline Stone pit & 3 & 102.5 & 154.7 & 124.8 & 26.9 & 22 \\
\hline Stone hole & 5 & 41.0 & 72.0 & 57.8 & 13.0 & 23 \\
\hline All above microhabitat types & 22 & 41.0 & 203.5 & 97.1 & 40.1 & 41 \\
\hline Total sampling points & 38 & 40.1 & 203.5 & 98.5 & 42.4 & 43 \\
\hline
\end{tabular}

of the total soil area of the plot, also showed significant variations in SOC one another. From above, highly varied SOC values clearly indicated that the microhabitat types were considerably different in soil properties one another. Therefore, it was unwise to collect soil sample only from one single microhabitat types for purpose of revealing soil nutrient levels.

\section{HETEROGENEITY OF SOIL ORGANIC CARBON IN INDIVIDUAL MICROHABITAT}

The variations of SOC in 8 individual microhabitats were listed in Tab. 3. CV values of soil organic carbon generally varied from $14 \%$ to $25 \%$, slightly lower than the $\mathrm{CV}$ values $(22 \% \sim 28 \%)$ for the same microhabitat types (Tab. 2), the maximum CV value was up to $57.3 \%$ in karren. These results implied that karst microhabitats were significantly heterogeneous in terms of SOC not only in the same microhabitat types, but also among microhabitats and in an individual microhabitat. Moreover, the results also indicated that microhabitat type of kar- not only by alternative distribution of soil and carbonate rock, but also by variations of SOC among sampling sites in an individual microhabitat. Because of high heterogeneity of outcrop karst forest soil, the results of the conventional sampling methods which disregarded soil heterogeneity may not be compared with one another. In the case of soil organic carbon, it was not representative based on the equivalent values from one single sample site or individual microhabitat, or from one microhabitat types.

There were two ways to calculate SOC content of the plot. One was to calculate arithmetic mean of 38 sampling points; another was to calculate weighted average of all soil sampling microhabitats. Because of the great heterogeneity of outcrop karst soil, arithmetic mean value was not more accurately indicated the content of SOC than weighted average value. Estimating soil organic carbon that might most approximately represent the soil property of a significantly heterogeneous outcrop karst region, the weighted value based on soil distributing size 
Tab. 3: Variation of contents of soil organic carbon in selected samples.

\begin{tabular}{|c|c|c|c|c|c|c|c|}
\hline Microhabitat type & $\begin{array}{c}\text { Microhabitat } \\
\text { No. }\end{array}$ & Number of sample & $\begin{array}{c}\text { Minimum } \\
(\mathrm{g} / \mathrm{kg})\end{array}$ & $\begin{array}{c}\text { Maximum } \\
(\mathrm{g} / \mathrm{kg})\end{array}$ & $\begin{array}{c}\text { Average } \\
\text { (g/kg) }\end{array}$ & $S D$ & $\begin{array}{l}C V \\
\text { (\%) }\end{array}$ \\
\hline \multirow[t]{3}{*}{ Soil } & $3-10$ & 3 & 75.6 & 106.9 & 93.9 & 16.3 & 17 \\
\hline & $3-25$ & 3 & 51.5 & 70.7 & 62.4 & 9.8 & 16 \\
\hline & $3-40$ & 3 & 40.1 & 61.3 & 53.0 & 11.3 & 21 \\
\hline \multirow[t]{2}{*}{ Rock-soil } & $3-17$ & 3 & 107.5 & 165.8 & 140.6 & 29.9 & 21 \\
\hline & $3-34$ & 3 & 91.4 & 139.2 & 109.8 & 25.7 & 23 \\
\hline \multirow[t]{3}{*}{ Karren } & $3-16$ & 3 & 61.3 & 98.0 & 76.7 & 19.0 & 25 \\
\hline & $3-21$ & 3 & 134.2 & 176.5 & 160.5 & 22.9 & 14 \\
\hline & $3-50$ & 3 & 47.3 & 169.3 & 106.6 & 61.1 & 57 \\
\hline
\end{tabular}

for all individual microhabitats in the plot must be taken into consideration. Weighted value based on soil distributing size could guarantee to obtain representative SOC contents in karst mountainous area.

In this study, a calculation method was proposed for estimating weighted SOC based on soil distributing size, and it was described by the following formula:

$$
\mathrm{SOC}=\sum_{j=1}^{m}\left[\sum_{i=1}^{n}\left(S_{i} \times \frac{A_{i}}{A_{j}}\right) \times \frac{A_{j}}{A}\right]
$$

Where SOC was the weighted values of soil organic carbon based on soil distributing size in the plot $(\mathrm{g} / \mathrm{kg})$, $j$ was microhabitat type $j, i$ was each individual microhabitat $i, \mathrm{~S}_{i}$ was the average soil organic carbon content of each individual microhabitat $i(\mathrm{~g} / \mathrm{kg}), \mathrm{A}_{i}$ was the soil distributing size of individual microhabitat $i\left(\mathrm{~m}^{2}\right), \mathrm{A}_{j}$ was the soil distributing size of microhabitat type $j\left(\mathrm{~m}^{2}\right)$, and A was the total soil distributing size in the plot $\left(\mathrm{m}^{2}\right)$.

According to the above formula, SOC content of weighted average value was $95.6 \mathrm{~g} / \mathrm{kg}$ from the total 38 sampling sites of the investigated plot (Approach 1), and $91.1 \mathrm{~g} / \mathrm{kg}$ from the three major microhabitat types (soil, rock-soil and karren) of covering 95\% soil distributing area of the plot (Approach 2; Tab. 4). Both SOC values were quite close $( \pm 3 \%)$. If $95 \%$ soil distributing area of these three major microhabitat types was used to represent the soil distributing area of the whole investigated plot (Approach 3), weighted SOC based on soil distributing size was $92.1 \mathrm{~g} / \mathrm{kg}$ (Tab. 4), quite close to the values of Approach 1. Therefore, there were small differences among the above three estimations (Approaches 1-3). By the way, if randomly sampling (Liu et al. 2005; Li et al. 2006; Zhang et al. 2006) a few points in relatively large and intact soil fragments to represent the plot, SOC content was only $81.5 \mathrm{~g} / \mathrm{kg}$ (Tab. 2), much lower than above values.

The weighted average SOC value of $92.1 \mathrm{~g} / \mathrm{kg}$ from Approach 3 had minor discrepancy from the arithmetic mean SOC value $98.5 \mathrm{~g} / \mathrm{kg}$ (Tab. 2) based on all sampling sites. This finding from Approach 3 was quite significant for study on nutrient status in heterogeneous soils of outcrop karst area. Firstly, in case of large numbers of soil microhabitats, only small numbers of soil samples were required to collect and analyze from dominating microhabitat types that accounted for around 95\% soil distributing of the studied area. Secondly, it was significant to avoid large discrepancies of nutrient levels, such as SOC, among various research results in outcrop karst areas for purpose of comparison. Suggestion of soil sampling was to mix soil samples collected from Approach 3 in the plot were capable of representing the soil nutrient status of the whole plot.

Tab. 4: Calculated average content of topsoil organic carbon in the plot (unit in $\mathrm{g} / \mathrm{kg}$ ).

\begin{tabular}{llll}
\hline & $\begin{array}{l}100 \% \text { soil } \\
\text { distributing area }\end{array}$ & $\begin{array}{l}95 \% \text { soil distributing } \\
\text { area }\end{array}$ & $\begin{array}{l}\text { 95\% soil distributing area } \\
\text { representing the whole plot }\end{array}$ \\
\hline $\begin{array}{l}\text { Estimated average value based on soil } \\
\text { distributing size quotient }\end{array}$ & 95.6 (Approach 1) & 91.1 (Approach 2) & 92.1 (Approach 3) \\
\hline
\end{tabular}




\section{CONCLUSIONS}

Soils in Maolan outcrop karst forest area were extremely heterogeneous in terms of soil distribution size, and SOC contents. It required an appropriate protocol to effectively study outcrop karst soil property. A representative sampling protocol based on soil distributing size weight proposed by this study successfully demonstrated advantage to effectively determine nutrient levels in heterogeneous soils of outcrop karst mountainous areas.

It is suggested that only small numbers of soil samples were required to collect and analyze from major mi- crohabitats that account for around 95\% soil distributing area of the studied karst. In this way, estimated average contents of nutrient matters such as SOC were capable of representing soil nutrient status of the whole studied karst areas, and of good comparisons among various research results as well. This soil sampling protocol could also contribut to study on heterogeneous soil property in non-karst areas.

\section{ACKNOWLEDGEMENTS}

This work was jointly funded by the National Key Basic Research Development Program (Grant No. 2006CB403200), Orientation Project of Knowledge Innovation Program of Chinese Academy of Sciences (No. kzcx2-yw-306), and the National Natural Science Foun- dation of China (Grant No. 40721002 and 40672112). We sincerely thank to Dr. ZSENI Anikó and another anonymous reviewer for their valuable comments and suggestions for improving the manuscript.

\section{REFERENCES}

Atalay, I., 1997: Red Mediterranean soils in karstic regions of Tauras Mountains, Turkey.- Catena, 28, 247-260.

Barahona, E. \& A. Iriarte, 2001: An overview of the present state of standardization of soil sampling in Spain.- The Science of the Total Environment, 264, 169-174.

Boerner, R. E. J., Scherzer, A. J. \& J. A. Brinkman, 1998: Spatial patterns of inorganic N, P availability, and organic $\mathrm{C}$ in relation to soil disturbance: a chronosequence analysis.- Applied Soil Ecology, 7, 159177.

Bramley, R. G. V. \& L. J. Janik, 2005: Precision agriculture demands a new approach to soil and plant sampling and analysis - Examples from Australia.Communications in Soil Science and Plant Analysis, 36, 9-22.

Cerda, A., 1998: Relationships between climate and soil hydrological and erosional characteristics along climatic gradients in Mediterranean limestone areas.Geomorphology, 25, 123-134.
Chen, Z., R., 1997: Karst forest investigation in Maolan.In: Zhu S. Q. (ed.) Study of Karst forest ecosystem II. Guizhou Science \& Technology Press, pp.167-172, Guiyang [in Chinese].

Donohue, S. J., 2002: Evaluation of soil nutrient variability for development of turfgrass soil test sampling methods.- Communications in Soil Science and Plant Analysis, 33, 3335-3345.

Drew, D. P., 1983: Accelerated soil erosion in a karst area: the Burren, Western Ireland.- Journal of Hydrology, 61, 113-124.

Fernando, A., Fernandes, J. P. A. \& J. F. S. Oliveira, 2001: Comparative evaluation of European methods for sampling and sample preparation of soils - the Portuguese contribution.- The Science of the Total Environment, 264, 181-186.

Gillieson, D. S., Cochrane, J. A. \& A. Murray, 1994: Surface hydrology and soil movement in an arid karst: the Nullarbor Plain, Australia.- Environmental Geology, 23, 125-133. 
He, Z. P., Jiang, Z. C. \& W. L. Lu, 2001: Effect of karst dynamic system on fertility of typical calcareous soils.- Carsologica Sinica, 20, 231-235 [in Chinese with English abstract].

Jhorar, R. K., Dam, J. C. V. \& W. G. M. Bastiaanssen, 2004: Calibration of effective soil hydraulic parameters of heterogeneous soil profiles.- Journal of Hydrology, 285, 233-247.

Kulmatiski, A. \& K. H. Beard, 2004: Reducing sampler error in soil research.- Soil Biology \& Biochemistry, 36, 383-385.

Lan, K., M., 1987: Karst forest preliminary investigation in Maolan.- In: Zhou, Z. X. (ed.) Scientific investigation report of Maolan karst forest. Guizhou Science \& Technology Press, pp. 148-161, Guiyang [in Chinese].

Leo, M. W. M., 1963: Heterogeneity of Soil of Agricultural Land in Relation to Soil Sampling.- Agricultural Land Food Chemistry, 11, 5, 432-434.

Li, Y. B., Xie, D. T. \& S. J. Wang, 2006: Impact of land cover types on the soil characteristics in karst area of Chongqing.- Journal of Geographical Sciences, $16,143-154$.

Liu, F., Wang, S. J. \& Y. S. Liu, 2005: The changes of soil quality in the process of karst rocky desertification and its evaluation of ecological environmental impact.- Acta Ecologica Sinica, 25, 639-644 [in Chinese, with English abstract].

Myeong, H. Y., Seung, J. J. \& S. Katsuyuki, 2003: Spacial variability of soil respiration in a larch plantation: estimation of the number of sampling points required.- Forest Ecology and Management, 175, 585-588.

Nelson, D. W. \& L. E. Sommers, 1982: Total carbon, organic carbon and organic matter.- In: Page, A.L., Miller, R.H. \& D.R. Keeney (eds.) Methods of Soil Analysis (2 ${ }^{\text {nd }}$ edition). American Society of Agronomy, pp. 539-577, Madison, Wisconsin.

Parise, M. \& V. Pascali, 2003: Surface and subsurface environmental degradation in the karst of Apulia (southern Italy).- Environmental Geology, 44, 247256.

Park, S. J. \& P. L. G. Vlek, 2002: Environmental correlation of three-dimensional soil spatial variability: a comparison of three adaptive techniques.- Geoderma, 109, 117-140.

Sauro, U., Ferrarese, F., Francese, R., Miola, M., Mozzi, P., Rondo, G.Q., Trombino, L. \& G. Valentini, 2009: Doline fills - case study of the Faverghera plateau (Venetian Pre-Alps, Italy).- Acta carsologica, 38, 1, 51-63.
Shang, C. \& H. Tiessen, 2003: Soil organic C sequestration and stabilization in karstic soils of Yucatan.Biogeochemistry, 62, 177-196.

Tamminen, P., 2003: Sampling and laboratory errors in forest soil analysis.- Communications in Soil Science and Plant Analysis, 34, 1193-1209.

Theocharopoulos, S. P., Wagner, U. G. \& J. Sprengart, 2001: European soil sampling guidelines for soil pollution studies.- The Science of the Total Environment, 264, 51-62.

Wang, Q. B., Li, L. \& H. Liu, 1998: Spatial heterogeneity of soil organic carbon and total nitrogen in a Xilin river basin grass land, Inner Mongolia.- Acta Phytoecologica Sinica, 22, 409-414 [in Chinese with English abstract].

Wang, S. J., Liu, Q. M. \& D. F. Zhang, 2004a: Karst rocky desertification in southwestern China: Geomorphology, landuse, impact and rehabilitation.- Land Degradation \& Development, 15, 115-121.

Wang, S. J., Li, R. \& L. Sun, 2004b: How types of carbonate rock assemblages constrain the distribution of karst rocky desertified land in Guizhou Province, P. R. China: Phenomena and mechanisms.- Land Degradation \& Development, 15, 123-131.

Whalen, J. K., 2004: Spatial and temporal distribution of earthworm patches in cornfield, hayfield and forest systems of southwestern Quebec, Canada.- Applied Soil Ecology, 27, 143-151.

Yang, Y. L., Tiang, C. Y. \& J. D. Sheng, 2002: Spatial variability of soil organic matter, total nitrogen phosphorus and potassium in cotton field.- Agricultural Research in the Arid Areas, 20, 3, 26-30 [in Chinese with English abstract].

Xiong, Y. \& Q. K. Li, 1987: Chinese Soil (2 $2^{\text {nd }}$ edition).China Science Press, pp. 39-66. Beijing, [in Chinese].

Zhang, P. J., Li, L. Q. \& G. X. Pan, 2006: Soil quality changes in land degradation as indicated by soil chemical, biochemical and microbiological properties in a karst area of southwest Guizhou, China.Environmental Geology, 51, 609-619. 